\title{
A Critique of Customer and Commodity
}

\author{
John M. Budd
}

For some good reasons, academic librarians see library users as customers, and library materials and access as commodities. However, there are some problems with the focus on consumerism and commodification. This paper examines a number of writings that advocate a customer service approach and the attendant view of library materials and access as commodities. The examination is informed by a substantial body of thought that addresses questions relating to customers and commodities in light of some cultural, social, and intellectual concerns. There are some problems, which are discussed in detail, with the popularly held notions of library users as customers and of library services as commodities.

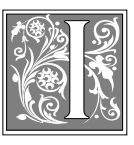

$n$ the twentieth century, librarianship has focused on the imperative of service as the first principle of the profession. Academic librarians are certainly no less concerned with service than are any other information professionals. Over time, academic librarians have built collections and developed services such as interlibrary loans, document delivery, and library instruction in order to facilitate the essential work of higher education. Although the service imperative has been expressed for a number of years (we need look no further than the five laws of librarianship articulated by S. R. Ranganathan), recent literature reflects an emphasis on customer service in libraries. To a considerable extent, customer service restates goals that libraries have long adhered to. For example, Suzanne Walters states that "If libraries are to sur- vive and thrive, they must realize that they are there to meet the needs of their customers and communities. Libraries cannot afford to simply be warehouses for information." ${ }^{11}$ Attention to the service that is emphasized by a customer service model is both necessary and correct. Clearly stated service goals help librarians keep the imperative foremost in mind. The model can continuously remind all in academic libraries that there is an external purpose that drives the library - the teaching, learning, and research that is at the heart of the college or university. Such an aid can be vital to the library's achieving its purpose.

Closely related to, and inherent in, a conception of customers and customer service is the view that the library trades in commodities. In a very real sense, such a view is accurate. There is no doubt that publishers and other information pro- 
ducers thrive by exchanging commodities, and libraries are part of that exchange through the acquisition of materials and the payment for access to information. An entity such as a publisher seeks to maximize (or at least optimize) profit, and seeks to do so in part by sell-

\section{It probably could be said that libraries could have had (and could now have) an even stronger focus on users and their needs.}

ing products to libraries. Also, libraries must work with purchasing offices in order to facilitate the trades in which the libraries are involved. Sherman Hayes and Don Brown have outlined the relationships that libraries have with corporations. They may be overstating the case when they say that "the library is a business, and will continue as a business for the foreseeable future, ${ }^{2}$ but it is undeniable that libraries must engage businesses such as publishers on the publishers' terms. However, the customer model extends the notion of libraries as handlers of commodities. Questions naturally arise as to the nature of the commodity and the relationships of the parties involved. The purpose of this paper is to explore some writings in the literature on customer service and related commodity exchange. These writings will be analyzed in the context of a substantial body of thought that addresses the implications of such a model.

\section{Customers and Customer Service}

Libraries have a history of concern regarding use and users and have tried to structure services, collections, and access to meet user needs. It probably could be said that libraries could have had (and could now have) an even stronger focus on users and their needs. The question to be addressed is whether a customer service stance accomplishes the goal of meeting user needs without creating a set of conceptual and practical problems for libraries. To answer this essential question, we have to look closely at the writings in the field on customers and customer service. An examination of these discourses can reveal the fundamental goals of the customer service approach and its overt or latent implications. At the heart of the examination is the realization that the language used to describe the stance adopted by libraries is not neutral; it may be culturally, politically, economically, and intellectually charged. In light of that realization, librarians have to wonder what it is they may be communicating and what that may mean to those inside and outside the profession.

Some of the writings on the subject articulate the purpose of a customer service orientation. Hernon and Altman tie the customer approach to service quality and elaborate on how to create and evaluate quality (an elusive entity). ${ }^{3}$ Others advocate quality as the purpose of the academic library. For example, MillsunMartula and Menon state that:

Many libraries, particularly academic libraries, have established liaison outreach programs in an attempt to get to know users better while also providing them with a greater amount of information about library programs and services on a more consistent basis.... However, an element of quality service is still absent. That element is the incorporation of users' personal needs and expectations into the development of the service. This requires librarians to establish an ongoing relationship with their customers in order to learn what their needs are. Staff become active listeners who then are able to process customer input on a continuous basis. ${ }^{4}$

The advocacy of a well-established relationship with the members of the library's community is aimed at accom- 
plishing the goal of meeting user needs. In a similar vein, Stoffle, Renaud, and Veldof write that:

The most fundamental change that has to occur among library employees is a switch from a focus on things and organizing library work around things to a focus on customers and their needs. Libraries must move from defining quality by the size of the inputs-and especially from valuing staff and collection size as "goods" in and of themselves. ... A All services and activities must be viewed through the eyes of the customers, letting customers determine quality by whether their needs have been satisfied. ${ }^{5}$

A shift from inputs to outcomes has been urged by others over the past several years. There is little (if anything) in these two statements that academic librarians would dispute.

However, there is one problematic aspect that inheres in both assertions. In focusing attention on customer expectations and determinations of quality, it is assumed that library users have the wherewithal to determine expectations and quality. It is an open question whether a member of the academic community knows (or even should know) what to expect from an organization as complex as a library. Knowable expectations could vary from the simple (an undergraduate student wanting access to required course readings) to the very complicated (a faculty member wanting an exhaustive corpus of recorded knowledge on a multidisciplinary topic, and wanting that corpus categorized and prioritized by relevance to her topic). On the other hand, a student or faculty member who has no awareness of the content and services available or possible will be unable to formulate normative expectations. If the library is to be constructed, in both a cognitive and practical sense, by customers, as Stoffle, Renaud, and Veldof say it should be, where do the limits for the library exist and how are they determined? In another context, Robinson says the public library should be the McDonald's of information service. ${ }^{6}$ Similarly, Woodsworth wishes the library could be more like her local hardware store. ${ }^{7}$ Is the academic library really to be conceived of as a retail outlet like McDonald's or a hardware store? These visions seem based on the notion that the library has a product that is as readily definable as the above examples and that "customers" know what they want and what the library has to offer. In fact, such a notion is central to the customer being able to determine quality and satisfaction.

Further, and much more important, the notion that equates what the library offers with the products of McDonald's and a hardware store objectifies, or reifies, the intellectual aims of the academic community. Although there is a frequent rhetorical insistence on the needs of individuals, the individuals get lost in the process of identifying people as customers. Weingand attempts to offer a rationale for use of the word customer: "The word customer, which implies payment for a product or service, is a better reflection of what actually transpires between the library and people in the community. With this term the mythology of the 'free' library is dispelled, and a more accurate metaphor for service is substituted." ${ }^{8}$ Weingand provides little, if any, evidence for the rhetoric of customer service being a more accurate description of the relationship between the library and its community. She does, however, present a more telling rationale for the shift in perspective:

Librarians who flinch at the word customer are operating out of an outmoded paradigm. This older paradigm portrays the library as a "public good," with as high a rank- 
ing on the "goodness" scale as the national flag, parenthood, and apple pie. As a public good, the library "should" receive public support. However, today's library is in increasingly tight competition for declining resources, and unless it adopts and masters the language and techniques of its competitors, it faces a future of declining support and significance. ${ }^{9}$

She is not alone in adopting such a rationale. Wehmeyer, Auchter, and Hirshon state that the purpose of a customer service plan is to "develop a core of satisfied customers, to offset the challenges from both internal and external competitors, and to enable the library to build budgeting allies on campus." 10

In addition to an ahistorical bent (that is, ignoring the many statements on service and cooperation in the literature of librarianship), there is, lurking just be-

\section{The customer, or consumer, be- comes a genuine source of material gain for the library.}

neath the surface of the rationales by Weingand and by Wehmeyer, Auchter, and Hirshon, a substantial shift of the economy of the library. Specifically, there is a shift in the kind of value envisioned for the library and its services. Although the traditional discourse on libraries, and even some of the discourse related to customer service, embraces use as a value of libraries (that is, a human purpose or utility underlying the thing), the discourse typified by the examples just given is centered on the exchange value of libraries and their services. Another example is provided in the public library environment by Walters, who states that "good service will result in customers voting for bond elections, contributing private dollars, and volunteering to support libraries. Poor customer service will result in lost elections and lost funding. It is as simple as that. Good customer service pays." ${ }^{11}$ Customer service is worth something material to the library-namely, enhancement of the library's standing within the larger institution and, thus, its material resources. The customer, or consumer, becomes a genuine source of material gain for the library. As Hawkes observes, "In consumer societies of the late twentieth century, exchange-value (a purely symbolic form) has become more real, more objective, than use-value (a material phenomenon). Objects are conceived, designed and produced for the purpose of making money by selling them, rather than for reasons of practical utility." ${ }^{12}$ Stated another way, the library's service, rather than being an end (in the sense of meeting the needs of the academic community), becomes a means (of garnering a larger piece of the budgetary pie). As such, there is an apparent contradiction in customer service discourse: although attention is to be focused on customers and their satisfaction, the desired end is really the material success of the library.

Such a shift in the perception of resources seems almost inevitable given the need for material resources as a means to reach the end of meeting user needs. What becomes especially problematic is the possibility of an accompanying shift in the vision of the library's purpose. The discourse on customers and customer service exhibits a tendency not to refer the individual to the totality; that is, there is a failure to place the individual phenomenon within the context of the whole. This tendency is evident in the repeated calls for identification of who the customers are. In a college or university, the response to such a call should be expressed as a tautology: the customers are the members of the academic community, and the members of the academic community are the customers. If the answer is anything other than this 
tautology, there is an apparent effort to privilege some community members at the expense of others. Stoffle, Renaud, and Veldof urge that librarians "must be sure that their work, activities, and tasks add value to the customer, and must be prepared to give up less-valued activities and institute new services and programs in very short time cycles." 13 If some services are to be discontinued because they are less valued than others, the question that follows is: Less valued by whom? In a culture defined by the increase of material resources as an end, the answer seems evident-the privileged customers will be those who, in some way, contribute to the instrumental end of the library. Schiller says: "This is a very basic shift indeed. In the reallocation of information resources now occurring . ..., one principle prevails. It is the market criterion - the ability to pay. This determines who will receive and who will be excluded from the benefits of the information-lubricated economy."14

The economic implications of use of the word customer as applied to library users indicates that advocates of the customer approach are applying a particular kind of categorization to library users. It already has been stated that the customer or consumer sometimes is seen as a source of material gain for the library and that such a view involves a lack of connection of the individual to the whole. This kind of categorization exemplifies what Lakoff calls a metonymic model. This means that a part (the economic persona of the customer) of a larger category (library users) stands for the category as a whole. Lakoff offers a set of characteristics that may typify the metonymic model:

There is a "target" concept A to be understood for some purpose in some context.

There is a conceptual structure containing both $\mathrm{A}$ and another concept B.
B is either a part of A or closely associated with it in that conceptual structure. Typically, a choice of B will uniquely determine $A$, within that conceptual structure.

Compared to A, B is either easier to understand, easier to remember, easier to recognize, or more immediately useful for the given purpose in the given context [emphasis added].

A metonymic model is a model of how A and B are related in a conceptual structure; the relationship is specified by a function from $B$ to A. ${ }^{15}$

The customer approach can be taken to be analogous to concept $\mathrm{B}$. That concept suits particular purposes-namely, categorizing the library user as an economic being. As has been seen, there are many instances in which such a categorization is useful, perhaps even necessary.

\section{Is every interaction between a library and a member of the academic community that of business and customer?}

One aspect of the metonymic model, though, is that the narrower concept tends to determine the broader one; that the categorization of customer tends to determine how the library user is seen. Again, questions arise: Is every interaction between a library and a member of the academic community that of business and customer? Is a library user a purely economic being? Is it desirable for the library to place the relationship between itself and the user primarily on material and instrumental grounds? This critique is founded on negative answers to these questions.

\section{Customers and Choice}

A hallmark of the customer approach is the belief that the customer is free to choose. The first (and probably most 
important) choice available to the customer is a binary one-to use the library or not. This level of choice is addressed by Weingand. She presents what she calls some looks at reality through the customer's eyes: "If the library is not open when I can use it, I'll find my information elsewhere," and "I really need these materials; if this library can't get them, I'll try another library or order them from the bookstore." 16 Such a view, placed in the academic environment, is echoed by Cline and Sinott, who state that:

some large academic departments have bypassed the library as an agent to provide selective dissemination services, supporting with departmental funds the acquisition of the necessary machine-readable tapes and the maintenance of staff to operate the system. This departmental initiative is one example of a more general phenomenon: academic libraries are finding it more and more difficult to keep up with the information needs of their users and the technologies that facilitate information transfer. ${ }^{17}$

The latter part of their statement is undoubtedly accurate, but it is questionable whether academic departments can still afford to maintain effective information services from their departmental budgets.

Some, such as Emery, highlight the importance of marketing initiatives in libraries as a mechanism to help customers choose from among the services offered by the library. ${ }^{18}$ Either implicitly or explicitly, these and other writers emphasize the relationship between choice and potential benefit. The benefits offered by libraries sometimes are expressed in economic terms, including savings in time and effort, consolidation of services, and potential material gain. As will become evident soon in the discussion of infor- mation and library services as commodities, the choices available to customers are assumed to be largely rational ones.

The preceding statement suggests that the assumptions underlying the view of choices of customers in libraries adhere to those of rational choice theory. The assumptions are frequently stated by rational choice theorists and are summarized by Green and Shapiro: "rational action involves utility maximization ... ; certain consistency requirements must be part of the definition of rationality ... ; each individual maximizes the expected value of his own payoff ... ; the relevant maximizing agents are individuals . . . ; [and] their models apply equally to all persons under study" [italics in original].$^{19}$ Green and Shapiro pay special attention to rational choice theory as applied to political science and, in their critique of the theory, maintain that the mistakes inherent in it "stem from a methoddriven rather than a problem-driven approach to research, in which practitioners are more eager to vindicate one or another universalist model than to understand and explain political outcomes." 20 It appears that the adherents of the customer approach seek to apply a similarly universalist model to library service.

Underlying the customer and customer service stance is particular emphasis on the assumption of utility maximization. For the customer to be able to determine the quality of a library and its services, that customer will, it is thought, apply standards based on a combination of cost minimization and gain. To accomplish this, he or she will have to be in a position to be aware of some a priori standards for benefit and cost. These are not easily determined, though, especially in advance. If a library user is informed (in the truest sense of the word) because of what the library has to offer, that informing is difficult or impossible to determine beforehand. In short, the criteria of benefit and cost are ambiguous in at least two ways: (1) library users may 
assess the two criteria very differently, even when the apparent need and outcome are very similar; and (2) an individual user may assess the criteria differently at different times because of a complex set of social, intellectual, and affective reasons (in opposition to the fifth assumption of rational choice theory). Even the "rational" in rational choice theory is ambiguous given the variations in human behavior, conceptions of rationality, and assessments of choice and the possibilities associated with it.

The problems with the theory do not end there. If rational choice is to have application, there should be at least the assumption that individuals are free to choose and, moreover, that their choices are constrained only by the limits of rationality. This is a decidedly questionable assumption, and it has been addressed by several thinkers, including Bunge: "The assumption that agents are completely free to choose ignores the constraints, compulsions, and traditions of various sorts that shape individual action. The theory overlooks the fact that one and the same individual behaves differently in different social systems, just as a molecule in a liquid body behaves differently at the bottom and at the surface." ${ }^{21}$ Although Bunge's last statement is itself somewhat reductionist, his criticism of the assumption holds. To be a bit more specific, the freedom to choose is constrained by the choices available. If, as Stoffle, Renaud, and Veldof maintain, libraries should abandon "less-valued" activities, the library user's choice is limited to the services provided by the library. Herein is one of a number of contradictions in customer service thinking. Weingand and others warn that if libraries are not providing something a customer wants, the customer will go elsewhere. However, if the library is structuring its services and activities according to what is valued by some, the customer base is essentially defined by the library. The openness touted by the cus- tomer approach is, it seems, a fiction. It would be equally mistaken to assert claims of openness with regard to McDonald's or a hardware store; they target their activities at very specific customers and their precise needs. The fact that they do not serve some members of society does not bother them in the least. Should the academic library adopt a similar stance? It cannot if it is to claim to serve the academic community.

\section{Information and Commodities}

If the view of library users as customers is to obtain, the offerings of the library must be seen as commodities. Frohmann maintains that the dominant stance in library and information science, which he terms the cognitive viewpoint, "consolidates on academic terrain those power relations which constitute information as a commodity, and persons as surveyable information consumers, within market economy conditions." ${ }^{22}$ As is true of the emphasis on customers and customer service, there is some necessity to seeing information as a commodity. Academic libraries must try to garner sufficient re-

\section{The openness touted by the customer approach is, it seems, a fiction.}

sources to pay for books, journal subscriptions, electronic sources, and access. A price is put on these entities by the producers, and libraries have to weigh relative costs of materials and access against the needs of their communities. The realization of the financial transactions that are inevitable between libraries and information producers is the basis of some economic analyses of aspects of library operations. ${ }^{23}$

As is the case with most research, some assumptions underlie economic analyses. These assumptions tend to stretch the commodification of information, to emphasize the commodity and ignore the 
informing quality, the intellectual value of information. As Marx recognized a century and a half ago:

Commodities come into the world in the shape of use-values, articles, or goods, such as iron, linen, corn, etc. This is their plain, homely, bodily form. They are, however, commodities, only because they are something two-fold, both objects of utility, and, at the same time, depositories of value. They manifest themselves therefore as commodities, or have the form of commodities, only in so far as they have two forms, a physical or natural form, and a value-form. ${ }^{24}$

The economic analyses at times attend to such an extent to the exchange value of information commodities that the use value is forgotten. For instance, Lewis looks at journal pricing in terms of library demand (the demand for the commodity by libraries) and personal demand (the demand for the commodity by individuals), and speaks of benefits as they relate to the prices libraries are charged for subscriptions. ${ }^{25}$ Although pricing is tied to production costs and potential markets (and choices exercised within those markets), there also are matters of content that affect subscription behavior. Also, in their analysis of personnel costs and productivity, Kingma and McCombs assume that all cataloging is equally valuable and all information is of equal value to users. ${ }^{26}$

Commodification of information has an inevitable effect. Information ceases to be seen as something that informssomething that has or conveys meaning - and, instead, is seen only as an object with an established exchange value. The effect is articulated by Lukacs:

The commodity can only be understood in its undistorted essence when it becomes the universal category of society as a whole. Only in this context does the reification produced by commodity relations assume decisive importance both for the objective evolution of society and for the stance adopted by men towards it. Only then does the commodity become crucial for the subjugation of men's consciousness to the forms in which this reification finds expression and for their attempts to comprehend the process or to rebel against its disastrous effects and liberate themselves from servitude to the "second nature" so created. $^{27}$

Therefore, the information as commodity is not different, at least in some expressions, from other commodities. Information as commodity is removed from information as meaning, as a meaningful communication process. It becomes nothing more than an object that has a price attached to it. This manifestation of objectification and reification of information as thing is what Marx referred to as the "fetishism" of commodities. Reification of information is not uncommon in library literature.

Some examples of reification are provided by some prominent authors in the field. It is embodied in the items that Hernon and Altman urge libraries to measure as reflections of their contributions to the academic mission:

The percentage of courses using the reserve reading room;

The percentage of students enrolled in those courses who actually checked out reserve materials;

The percentage of courses requiring term papers based on materials from the library;

The number of students involved in those courses;

The percentage of students who checked out library materials;

The percentage of faculty who checked out library materials; 
The percentage of courses using reading packets based on materials photocopied from the library's collection;

The number of articles and books published by faculty members; and

The number of references cited in faculty publications from materials contained in the collection. ${ }^{28}$

These measures have no direct connection to learning, research, or intellectual activity in general. Rather, they deal with the handling of things, objects. Getz is even more explicit in objectifying library operations. He posits that all of academic library management is predicated on the treatment of the products and activities of libraries as things, especially economic things. Getz says: "An analyst states objectives for the library in terms of benefits gained for costs incurred, decision by decision. The criterion for success is whether a change in library operation has increased the value of library services to the people who pay for them, net of the costs they incur." ${ }^{29}$ His entire program is based on a notion of exchange value (and rational choice). What the library offers is worth something to the user; that is, the user is willing to expend something (usually time) in order to get something that is worth more than what is expended. Exchange value is the foundation of quality in Getz's conception:

The "better" library yields services that are more valuable than they cost, indeed, as much more valuable as possible. The library that does this best is an efficient library. Efficiency is a more demanding standard than simply effectiveness. An effective library is one that makes a difference. If longer hours attract more users, hours are effective in this regard. To determine whether the extra hours of service increase efficiency, however, the added value of the extra use must be shown to be worth the cost of providing the extra hours. ${ }^{30}$

Commodification of information is not without its critics, in the library and other fields. Approaching the matter from a sociological perspective, Schoonmaker observes that the process of commodification is one of the characteristics of advanced capitalism. The commodification of information appears to be enhanced and accelerated by the proliferation of electronic media. She writes: "Rather than introducing a qualitatively different type of information society, microelectronics technologies have made it

\section{If the library is a part of trading in commodities, it will likely come to see itself as part of the production/ consumption cycle.}

technically possible to extend the process of commmodification into digital forms of production and exchange." ${ }^{31}$ Electronic media emphasize the flow of the commodity of information from producers to expanding markets. It is clear that reification is inherent in the flow of the commodity. Dennis adopts an even more critical stance as he examines the conflicts arising over power and knowledge. He makes the point that both information and the individual are objectified as a logic of consumption becomes dominant. He raises the very important point that "A marketplace of ideas (images, speech) is not the same as ideas (images, speech) in the marketplace." 32 Along with commodification comes identification with the process of commodifying. If the library is a part of trading in commodities, it will likely come to see itself as part of the production/consumption cycle. Such a view emphasizes yet further the reification of information as commodity. Given this transformation, we should pay particular attention to Schiller's warning: 
In recent years, libraries are increasingly being put into the position of adjunct to and facilitator for the commercial information industry. Despite an initial reluctance to become involved in commercial practices - i.e., charging users for information, relying on private vendors for data bases, contracting out functions to private firms, etc.-libraries now almost routinely adopt such practices. Meanwhile, the distinction between a library and a commercial enterprise narrows. The library's options to preserve its vital social role also diminish. ${ }^{33}$

\section{Discussion}

One of the most important things to keep in mind with regard to customers and commodities is that the language librarians use to describe their purpose and activities inevitably will define, even if they do not initially reflect, thought. For instance, even though Brown says that "it is useful to understand more about the service interaction and what it is that makes 'buying' and evaluating a service (such as reference service) different for the customer than 'buying' and evaluating a material product," she proceeds to speak of consumption and retail analogy to describe reference work in academic libraries. ${ }^{34}$ The language employed is a powerful shaping force, and that force, in this context, is tied to the discourse of consumption. Baudrillard says that "consumption is the virtual totality of all objects and messages constituted in a more or less coherent discourse. Consumption, in so far as it is meaningful, is a systematic act of the manipulation of signs [italics in original]." 35 Signs, in the Saussurean linguistic sense, are composed of the totality of the signifier and the signified. The focus on the customer approach and information as commodity embodies a shift from primary attention on the signified to attention centered on the signifier. The signified is the content, concept, or idea; the signifier is an expression, a sound-image, or form. In other words, the transformation is one from substance to form.

In another sense, the transformation moves from semantics (meaning) to rhetoric (expression). Emery writes that "'Without consumers, the marketer of economic goods and services does not have a market.' Similarly, without readers the library lacks its raison d'être. Though in one case an individual may be called a 'consumer' and in the other a 'reader,' the difference is purely semantic." ${ }^{36}$ In actuality, Emery is dismissing the semantic and championing the rhetorical. In the more thoughtful connections of library purpose to capital, a kind of schizophrenia reigns. The schizoid tendency is evident in the conflict that Repo struggles with. Although he advocates economic analysis of information, he repeatedly reminds the reader (and himself) of the use value of information ("The value of information is fully explicated in its use. ${ }^{\prime 37}$ ) In less thoughtful treatments certainty governs. For example, in urging the customer approach, Weingand advocates the "paradigm" of consumerism as superior to the view of the library as a public good (noted above). It seems to matter little that the language adopted is a usurpation of ideas that either do not apply or apply imperfectly to the library's situation.

Weingand's statement is not value neutral. In fact, it is an exemplar of the Foucauldian will to truth and knowledge which, as Foucault observes, "like the other systems of exclusion, relies on institutional support: it is both reinforced and accompanied by whole strata of practices," and is "profoundly accompanied by the manner in which knowledge is employed in a society, the way it is exploited, divided and, in some ways, attributed. . . . [T] his will to knowledge, thus reliant upon institutional support and distribution, tends to exercise a sort of pres- 
sure, a power of constraint upon other forms of discourse." 38 The impact on knowledge is profound and debilitating. The effect is best expressed by Lyotard:

The nature of knowledge cannot survive unchanged within this context of general transformation. . . . The relationship of the suppliers and users of knowledge to the knowledge they supply and use is now tending, and will increasingly tend, to assume the form already taken by the relationship of commodity producers and consumers to the commodities they produce and consume-that is, the form of value. Knowledge is and will be produced in order to be sold, it is and will be consumed in order to be valorized in a new production: in both cases, the goal is exchange. Knowledge ceases to be an end in itself, it loses its "use-value." ${ }^{39}$

Finally, the discourse on customer and commodity in the academic library takes on the characteristics of ideology. Specifi- cally, it is ideological in that it asserts a dominance over other discourses, and does so through distortion of context that all but eliminates any teleological sense. As Hawkes points out, two aspects of ideology - "instinctive deferral to 'the facts' as they are immediately represented to us, and blind faith in instrumental science-are the most dangerous effects of commodity fetishism. In order for a thing to become a commodity, the coercive power of human reason must be exerted over the thing-in-itself: we must represent it as what it is not, and then take the representations for the reality." ${ }^{40}$ Ultimately, librarians need to take care with the language they adopt, and with the facility with which they use it to shape concepts. That the language of consumerism and commodification dominates beyond the sphere of libraries is not sufficient reason to accept it uncritically. The library's language, and practice, should flow from as clear an idea of purpose as possible. And librarians should examine purpose independently from the pressures of capitalism and consumption.

\section{Notes}

1. Suzanne Walters, Customer Service: A How-to-Do-It Manual for Librarians (New York: NealSchuman, 1994), 1.

2. Sherman Hayes and Don Brown, "The Library As a Business: Mapping the Pervasiveness of Financial Relationships in Today's Library," Library Trends 42 (winter 1994): 405. 1996).

3. Peter Hernon and Ellen Altman, Service Quality in Academic Libraries (Norwood, N.J.: Ablex,

4. Christopher Millson-Martula and Vanaja Menon, "Customer Expectations: Concepts and Reality for Academic Library Services," College \& Research Libraries 56 (Jan. 1995): 34.

5. Carla J. Stoffle, Robert Renaud, and Jerilyn R. Veldof, "Choosing Our Futures," College $\mathcal{E}$ Research Libraries 57 (May 1996): 220.

6. Charles Robinson, “Can We Save the Public's Library?" Library Journal 114 (Sept. 1989): 147-52.

7. Anne Woodsworth, "Service à la Your Neighborhood Store," Library Journal 121 (Aug. 1996): 49.

8. Darlene E. Weingand, Customer Service Excellence: A Concise Guide for Librarians (Chicago: ALA, 1997), 2.

9. Ibid., 3.

10. Susan Wehmeyer, Dorothy Auchter, and Arnold Hirshon, "Saying What We Will Do, and Doing What We Say: Implementing a Customer Service Plan," Journal of Academic Librarianship 22 (May 1996): 179.

11. Walters, Customer Service, 1.

12. David Hawkes, Ideology (London: Routledge, 1996), 169.

13. Stoffle, Renaud, and Veldof, "Choosing Our Futures," 220. 
14. Herbert I. Schiller, Culture Inc.: The Corporate Takeover of Public Expression (New York: Oxford Univ. Pr., 1989), 75.

15. George Lakoff, Women, Fire, and Dangerous Things: What Categories Reveal about the Mind (Chicago: Univ. of Chicago Pr., 1987): 84-85.

16. Weingand, Customer Service Excellence, 115.

17. Hugh F. Cline and Loraine T. Sinnott, The Electronic Library: The Impact of Automation on Academic Libraries (Lexington, Mass.: Lexington Books, 1983), 6.

18. Charles D. Emery, Buyers and Borrowers: The Application of Consumer Theory to the Study of Library Use (New York: Haworth Pr., 1993).

19. Donald P. Green and Ian Shapiro, Pathologies of Rational Choice Theory: A Critique of Applications in Political Science (New Haven, Conn.: Yale Univ. Pr., 1994), 14-17.

20. Ibid., 33.

21. Mario Bunge, Finding Philosophy in Social Science (New Haven, Conn.: Yale Univ. Pr., 1996), 365 . On pages 382-84, Bunge presents a summary of what he sees as the fatal flaws of rational choice theory.

22. Bernd Frohmann, "The Power of Images: A Discourse Analysis of the Cognitive Viewpoint," Journal of Documentation 48 (Dec. 1992): 368.

23. See, for instance, David W. Lewis, "Economics of the Scholarly Journal," College \& Research Libraries 50 (Nov. 1989): 674-88; Michael A. Stoller, Robert Christopherson, and Michael Miranda, "The Economics of Professional Journal Pricing," College \& Research Libraries 57 (Jan. 1996): 9-21; Bruce R. Kingma and Philip B. Eppard, "Journal Price Escalation and the Market for Information: The Librarian's Solution," College \& Research Libraries 53 (Nov. 1992): 523-35.

24. Karl Marx, Capital: A New Abridgement (New York: Oxford Univ. Pr., 1995), 22.

25. Lewis, "Economics of the Scholarly Journal."

26. Bruce R. Kingma and Gillian M. McCombs, "The Opportunity Costs of Faculty Status for Academic Librarians," College \& Research Libraries 56 (May 1995): 258-64.

27. Georg Lukacs, History and Class Consciousness: Studies in Marxist Dialectics, trans. Rodney Livingstone (Cambridge, Mass.: MIT Pr., 1971), 86.

28. Hernon and Altman, Service Quality in Academic Libraries, 1-2.

29. Malcolm Getz, "Analysis and Library Management," in Academic Libraries: Research Perspectives, eds. Mary Jo Lynch and Arthur Young (Chicago: ALA, 1990), 192.

30. Ibid., 194.

31. Sara Schoonmaker, "Trading On-Line: Information Flows in Advanced Capitalism," Information Society 9 (Jan.-Feb. 1993): 47.

32. Dion Dennis, "License and Commodification: The Birth of an Information Oligarchy," Humanity and Society 17 (Feb. 1993): 64.

33. Schiller, Culture Inc., 80.

34. Janet Dagenais Brown, “Using Quality Concepts to Improve Reference Services," College \& Research Libraries 55 (May 1994): 213.

35. Jean Baudrillard, Jean Baudrillard: Selected Writings, ed. Mark Poster (Stanford, Calif.: Stanford Univ. Pr., 1988), 22.

36. Emery, Buyers and Borrowers, 20.

37. Aatto J. Repo, "The Value of Information: Approaches in Economics, Accounting, and Management Science," Journal of the American Society for Information Science 40 (Mar. 1989): 82.

38. Michel Foucault, The Archaeology of Knowledge and the Discourse on Language, trans. A. M. Sheridan Smith (New York: Pantheon Books, 1972), 219.

39. Jean-François Lyotard, The Postmodern Condition: A Report on Knowledge, trans. Geoff Bennington and Brian Massumi (Minneapolis: Univ. of Minnesota Pr., 1984), 4-5.

40. Hawkes, Ideology, 138. 